\title{
METODE PENGEMBANGAN SUMBER DAYA MANUSIA (PEGAWAI) UIN RADEN INTAN LAMPUNG DAN IMPLIKASINYA
}

\author{
Amirudin \\ Universitas Islam Negeri Raden Intan Lampung \\ amirudin@radenintan.ac.id
}

\begin{abstract}
Abstrak
Manajemen sumber daya manusia adalah penyediaan staf, pengembangan sumber daya manusia, kompensasi, keselamatan, dan kesehatan serta hubungan karyawan dan buruh untuk mencapai tujuan-tujuan individu ataupun organisasi. Manajemen sumber daya manusia mempunyai kekhususan dibandingkan dengan manajemen secara umum. Manajemen sumber daya manusia merupakan suatu pengakuan terhadap pentingnya sumber daya manusia atau tenaga kerja dalam organisasi. Tujuan manajemen sumber daya manusia dijabarkan dalam empat tujuan yang lebih operasional sebagai berikut; 1. Tujuan social, 2. Tujuan organisasi: 3. Tujuan fungsi: 4. Tujuan personel. Untuk mencapai tujuan-tujuan manajemen sumber daya manusia tersebut, perlu dilakukan oleh lembaga pendidikan agar semua fungsi SDM dalam lembaga pendidikan khususnya UIN Raden Intan berjalan stabil dan seimbang. Dengan demikian semua tujuan pendidikan secara keseluruhan yang sudah direncanakan dapat terwujud dengan baik.
\end{abstract}

Kata Kunci: Manajemen, Sumber Daya Manusia 


\section{PENDAHULUAN}

Secara bahasa manajemen berasal dari bahasa Inggris berasal dari kata "management" yang berarti pengelolaan, ketata laksanaan, atau tata pimpinan. Sementara dalam kamus Inggris Indonesia karangan John M. Echols dan Hasan Shadily (1995 : 372) managemen berasal dari akar kata to manage yang berarti mengurus, mengatur, melaksanakan, mengelola, dan memperlakukan. Sementara manajemen menurut istilah adalah proses mengkordinasikan aktifitas-aktifitas kerja sehingga dapat selesai secara efesien dan efektif dengan dan melalui orang lain (Robbin dan Coulter, 2007:8). Sedangkan Sondang P Siagian (1980: 5) mengartikan manajemen sebagai kemampuan atau keterampilan untuk memperoleh suatu hasil dalam rangka mencapai tujuan melalui kegiatan-kegiatan orang lain.

Manusia diberi anugerah fisik, akal dan nafsu menjadikan dirinya berperan sangat dominan di muka bumi ini,terutama dalam mengelola, memanfaatkan dan mengatur sumberdaya alam yang menjadi anugerah Allah swt. Manusia sebagai makhluk multi potensi, yang paling utama adalah diberi potensi akal dan nafsu serta jasad yang indah terus melakukan dinamika kemajuan dan perkembangan peradaban di muka bumi ini.

Perubahan-perubahan mendasar dalam lingkungan kehidupan manusia menuntut peran manajemen sumber daya manusia dalam pengembangan fungsi manajemen sumber daya manusia dan departemen sumber daya manusia. Perkembangan kehidupan manusia seiring dengan perkembangan dan kemajuan teknologi dan informasi secara dramatis ditandai dengan bergejolaknya lingkungan yang serba digital, dan semakin kompleks, tidak dapat diprediksi, serta meningkatnya biaya-biaya operasi sehingga tekanan kompetitif menciptakan tantangan bagi organisasi yang ingin meraih keunggulan kompetitif. Organisasi tidak dapat menentukan secara pasti hal-hal yang berkenaan dengan supply tenaga kerja yang meliputi hal berikut. (1) Bagaimana menarik, mempertahankan, dan memotivasi sumber daya manusia yang semakin beragam. (2) Bagaimana cara mendapatkan individu yang memiliki keterampilan, pengetahuan, dan kemampuan yang tepat. (3) Bagaimana mengarahkan sumber daya manusia yang ada agar dapat menjadi sumber keunggulan kompetitif, baik secara domestik maupun internasional. Selanjutnya, manajemen sumber daya manusia merupakan pemanfaatan sejumlah individu untuk mencapai tujuantujuan perusahaan. Konsekuensinya, para manajer di setiap tingkat harus melibatkan diri mereka dengan manajemen sumber daya manusia. Manajemen sumber daya manusia pada hakikatnya adalah penerapan manajemen khusus untuk sumber daya manusia. Maka dari itu, manajemen sumber daya manusia didefinisikan sebagai seni untuk merencanakan, mengorganisasikan, mengarahkan, dan mengendalikan kegiatan-kegiatan sumber daya manusia atau karyawan dalam mencapai tujuan perusahaan. Hal 
ini sejalan dengan beberapa pendapat yang telah dikemukakan oleh ahli-ahli manajemen sumber daya manusia yang akan diuraikan berikut ini. Pendapat yang dikemukakan oleh Flippo mengenai manajemen sumber daya manusia adalah perencanaan, pengorganisasian, pengarahan, dan pengawasan kegiatan-kegiatan pengadaan, pengembangan, pemberian kompensasi, pengintegrasian, pemeliharaan, dan pelepasan sumber daya manusia agar tercapai berbagai tujuan individu, organisasi, dan masyarakat. Sejalan dengan pendapat sebelumnya, French mengemukakan manajemen sumber daya manusia adalah penarikan, seleksi, pengembangan, penggunaan, dan pemeliharaan sumber daya manusia oleh perusahaan. Mondy (2008) mengemukakan fungsi-fungsi operasional manajemen sumber daya manusia, yaitu penyediaan staf, pengembangan sumber daya manusia, kompensasi, keselamatan, dan kesehatan serta hubungan karyawan dan buruh. Berdasarkan pendapat-pendapat para ahli manajemen sumber daya manusia tersebut, dapat disimpulkan bahwa manajemen sumber daya manusia adalah penyediaan staf, pengembangan sumber daya manusia, kompensasi, keselamatan, dan kesehatan serta hubungan karyawan dan buruh untuk mencapai tujuan-tujuan individu ataupun organisasi. Manajemen sumber daya manusia mempunyai kekhususan dibandingkan dengan manajemen secara umum. Hal ini disebabkan yang di-manage adalah manusia. Oleh karena itu, keberhasilan atau kegagalan manajemen sumber daya manusia ini akan mampu mempunyai dampak yang sangat luas. Manajemen sumber daya manusia merupakan suatu pengakuan terhadap pentingnya sumber daya manusia atau tenaga kerja dalam perusahaan. Selanjutnya penting dalam pemanfaatannya di berbagai fungsi dan kegiatan untuk mencapai tujuan perusahaan. Manajemen sumber daya manusia juga diperlukan untuk meningkatkan daya guna dan hasil guna sumber daya manusia dalam perusahaan dengan memberikan satuan kerja yang efektif kepada perusahaan.

Tujuan manajemen sumber daya manusia adalah meningkatkan kontribusi sumber daya manusia (karyawan) terhadap perusahaan dalam mencapai produktivitas perusahaan yang bersangkutan. Hal ini dapat dipahami bahwa semua kegiatan perusahaan dalam mencapai misi dan tujuannya sangat tergantung pada manusia yang mengelola perusahaan tersebut. Oleh sebab itu, sumber daya manusia (karyawan) tersebut harus dikelola secara benar sehingga berdaya guna dan berhasil guna dalam mencapai misi dan tujuan perusahaan. Tujuan manajemen sumber daya manusia dijabarkan dalam empat tujuan yang lebih operasional sebagai berikut; 1. Tujuan sosial: bertanggung jawab secara sosial, dalam hal kebutuhan, dan tantangan-tantangan yang timbul dari masyarakat. Suatu perusahaan yang berada di tengah-tengah masyarakat diharapkan dapat membawa manfaat atau keuntungan bagi masyarakat. Oleh sebab itu, suatu lembaga pendidikan juga mempunyai tanggung jawab dalam mengelola 
sumber daya manusianya agar agar selalu mengikuti perkembangan kehidupan masyarakat. 2. Tujuan organisasi: mengenal bahwa manajemen sumber daya manusia itu ada (exist) sehingga perlu memberikan kontribusi terhadap pendayagunaan organisasi secara keseluruhan. Manajemen sumber daya manusia bukanlah suatu tujuan dan akhir suatu proses, melainkan suatu perangkat atau alat untuk membantu tercapainya suatu tujuan organisasi secara keseluruhan. Oleh sebab itu, suatu unit atau bagian manajemen sumber daya manusia di suatu lembaga pendidikan diadakan untuk melayani bagianbagian yang ada dalam lembaga pendidikan. 3. Tujuan fungsi: memelihara (maintain) kontribusi bagian-bagian lain agar mereka (sumber daya manusia dalam tiap bagian) melaksanakan tugasnya secara optimal. Dengan kata lain, setiap sumber daya manusia atau karyawan itu menjalankan fungsinya dengan benar. 4. Tujuan personel: membantu karyawan mencapai tujuantujuan pribadinya dalam pencapaian tujuan lembaga pendidikan. Tujuantujuan pribadi karyawan seharusnya dipenuhi. Hal ini sudah merupakan motivasi dan pemeliharaan terhadap karyawan itu.

Untuk mencapai tujuan-tujuan manajemen sumber daya manusia seperti yang telah dikemukakan di atas, maka sumber daya manusia harus dikembangkan, melalui pememeliharaan sejumlah dan tipe pegawai atau karyawan sebagai sumber daya manusia. Hal ini perlu dilakukan oleh lembaga pendidikan agar semua fungsi SDM dalam lembaga pendidikan berjalan stabil dan seimbang. Dengan demikian semua tujuan pendidikan secara keseluruhan yang sudah direncanakan dapat terwujud dengan baik.

Selanjutnya, potensi manusia yang berupa akal, nafsu, hati (jiwa) dan fisik secara komperehensip telah menjadikan wajah dunia semakin maju dan beradab dengan memanfaatkan unsur-unsur potensi alam. Karena itu, agar manusia dapat eksis melakukan inovasi dan modernisasi dunia dengan selalu memepertimbangkan kemaslahatan dan kesejahteraan bagi umat manusia dibutuhkan ilmu pengetahuan dan sains serta skills atau keterampilan yang dapat dijadikan dasar pengelolaan sumber daya alam.

Potensi yang dimiliki manusia dalam ilmu manajemen diartikan sebagai sumber daya manusia (SDM). Dan inilah yang harus selalu dikembangkan. Mengapa Sumber Daya Manusia perlu dikembangkan? , karena manusia adalah salah satu Sumber Daya yang di dalamnya terdapat potensi insaniyah yang dapat dikembangkan, seperti potensi akal, fisik dan hati (qalbu). Sebagiamana diungkapkan oleh Gouzali ; "Pengembangan Sumber Daya Manusia (SDM) merupakan kegiatan yang harus dilakukan 
oleh organisasi agar pengetahuan (knowledge), kemampuan (ability), dan keterampilan (skill) sesuai dengan tuntutan pekerjaan yang mereka lakukan.1

Munurut Hasibuan (2003:3), Sumber daya manusia (SDM) adalah semua manusia yang terlibat dalam suatu organisasi dalam mengupayakan terwujudnya tujuan organisasi tersebut. Nawawi (2005), membagi pengertian SDM kedalam tiga pengertian.

a. Sumber daya manusia adalah manusia yang bekerja di lingkungan suatu organisasi (disebut juga personil, tenaga kerja, pekerja atau karyawan).

b. Sumber daya manusia adalah potensi manusiawi sebagai penggerak organisasi dalam mewujudkan eksistensinya.

c. Sumber daya manusia adalah potensi yang merupakan asset dan berfungsi sebagai modal (non material/non finansial) didalam organisasi bisnis, yang dapat mewujudkan menjadi potensi nyata (real) secara fisik dan non-fisik dalam mewujudkan eksistensi organisasi.

Disamping itu, manusia adalah makhluk Tuhan yang kompleks dan unik serta diciptakan dalam integrasi dua substansi yang tidak berdiri sendiri yaitu tubuh ( fisik/ jasmani) sebagai unsur materi, dan jiwa yang bersifat non materi. Hubungan kerja yang paling intensif di lingkungan organisasi adalah antara pemimpin dengan para pekerja (staf) yang ada di bawahnya. Hubungan kerja semakin penting artinya dalam usaha organisasi mewujudkan eksistensinya di lingkungan tugas yang lebih luas dan kompetetif pada masa yang akan datang.

Sumber daya manusia memiliki keinginan, harga diri, pikiran, hak asasi, ingin dihormati dan lain-lain. Oleh karena itu sumber daya manusia harus diperlakukan sama secara hati-hati dan penuh kearifan.Sumber daya manusia adalah ujung tombak pelayanan, sangat diandalkan untuk memenuhi standar mutu yang diinginkan oleh suatu organisasi atau perusahaan. Untuk mencapai standar mutu tersebut, maka harus diciptakan situasi yang mendukung pelayanan yang memuaskan subjek pelayanan.

Berdasarkan beberapa pengertian tersebut dapat disimpulkan bahwa sumber daya manusia adalah manusia dengan segala potensi yang dimilikinya baik fisik maupun psikis yang dapat didayagunakan untuk mencapai tujuan suatu lembaga atau organisasi.

Pengembangan SDM merupakan suatu upaya peningkatan pengetahuan, sikap dan keterampilan dari manusia itu sendiri melalui berbagai cara atau metode. Pengertian pengembangan sumber daya manusia dapat di katagorkan secara makro maupun secara mikro. Pengembangan sumber daya manusia secara makro adalah suatu proses peningkatan kualitas atau kemampuan manusia dalam rangka mencapai tujuan pembangunan

1Saydam, Gouzali, 2000, ManajemenSumberDayaManusia (Human Resources Management): SuatuPendekatanMikro (Dalam Tanya Jawab), Jakarta, PenerbitDjamabatan, Cet. II, hal. 496 
bangsa yang mencakup perencanaan, pengembangan, dan pengelolaan. Sedangkan pengembangan sumber daya manusia secara mikro adalah suatu proses perencanaan pendidikan,pelatihan dan pengelolaan tenaga kerja atau karyawan untuk mancapai suatu hasil yang optimal

Percepatan transformasi teknologi dan informasi dari waktu ke waktu sebagai hasil rekayasa manusia "moderen" menuntut kita untuk dapat mengimbangi dan mengaplikasikannya. Karena banyak pekerjaan di sekitar kita sudah berbasis ICT. Jika tidak, maka pekerjaan tidak dapat diselesaikan dengan "smart and Smooth"

Jadi Pengembangan SDM merupakan salah satu cara efektif untuk menghadapi tantangan pekerjaan dalam sebuah organisasi, lembaga, atau institusi, sehingga memiliki daya kompetetif yang lebih berkelanjutan (sustainable). Seseorang atau sebuah organisasi atau lembaga yang berkualitas selalu berupaya menciptakan peningkatan pengetahuan, keterampilan dan kemampuan (karir, prestasi, kualitas) sesuai kapasitasnya.

Banyak cara yang dapat digunakan untuk pengembangan SDM, antara lain pengembangan SDM melalui Gugus Kendali Mutu, melalui Motivasi Kerja, Pembinaan Karier, Pengawasan Promosi, Mutasi, Pemberdayaan dan Assesment Center serta lainnya. Pada Penelitian ini Peneliti ingin mengkaji dan menelaah metode-metode atau strategi Pengembangan SDM berdasarkan teori-teori manajemen yang pada akhirnya dapat dijadikan referensi bagi pengembangan SDM

Menurut peneliti, pengembangan potensi manusia (SDM) (human resource development) merupakan kegiatan yang sangat penting. Meski biaya yang dibutuhkan banyak, namun ini menjadi investasi jangka panjang untuk pengembangan sebuah institusi. Pengembangan Sumber Daya Manusia (SDM) dapat dilakukan secara formal dan informal. Pengembangan SDM secara formal ditugaskan oleh organisasi atau lembaga untuk mengikuti pendidikan atau latihan baik yang dilakukan oleh organisasi ataupun oleh lembaga pendidikan atau pelatihan. Sedangkan pengembangan secara informal yaitu, karyawan atau manusia atas keinginan dan usaha sendiri melatih dan mengembangkan dirinya dengan mempelajari buku-buku literature yang ada hubungannya dengan pekerjaan atau jabatannya. Pengembangan informal ini menunjukkan bahwa manusia atau karyawan tersebut berkeinginan keras untuk maju dengan cara meningkatkan kemampuan kerjanya.2

Ada beberapa metode yang dapat dilakukan untuk pengembangan potensi manusia (SDM) (human resource development) baik secara formal

2Hasibuan Malayu, 1996 , Manajemen Sumber Daya Manusia, Cet. III, CV. Jakarta, CV. Haji Mas Agung, hal. 72 
ataupun non formal sebagaimana dijelaskan di atas yang akan dijadikan objek penelitian ini. Dengan menelaah dan mengkaji karakteristik, langkahlangkah, kelebihan dan kekurangan masing-masing metode pengembangan SDM diharapkan dapat memberikan informasi bagi pihak yang berkeinginan untuk selalu mengembangkan SDM sesuai dengan potensi dan talenta yang dimiliki oleh setiap individu. Terlebih bagi pihak yang memiliki organisasi, lembaga atau instansi yang memiliki personalia atau pegawai yang senantiasa harus berinovasi mengembangkan SDM nya.

\section{METODE PENELITIAN}

Metode pengumpulan data yang digunakan dalam analisis ini adalah metode dokumentasi. Metode ini dapat diartikan sebagai cara pengumpulan data dengan cara memanfaatkan data-data berupa buku, cacatan (dokumen) sebagaimana dijelaskan oleh Sanapiah Faesal sebagai berikut : Metode dokumenter, sumber informasinya berupa bahan-bahan tertulis atau tercatat. Pada metode ini petugas pengumpulan data tinggal mentransfer bahan-bahan tertulis yang relevan pada lembaran-lembaran yang telah disiapkan untuk mereka sebagaimana mestinya. ${ }^{3}$

Dokumen adalah catatan tertulis tentang berbagai kegiatan atau peristiwa pada waktu yang lalu. Metode ini digunakan untuk memperoleh data tentang :

1) Teori-teori Metode Pengembangan SDM

2) Karakteristik Sumber Daya Manusia (SDM)

3) Metode Pengembangan SDM

4) Karakteristik Metode Pengembangan SDM

5) Implikasi Pengembangan SDM

Teknik analisis data dalam penelitian ini menggunakan analisis kualitatif dan bersifat induktif, yaitu suatu analisis berdasarkan data yang diperoleh, selanjutnya dikembangkan pola hubungan tertentu. Adapun langkah-lanmgkah yang harus dilalui dalam analisis data adalah reduksi data, display data, dan conclusion drawing atau verification. ${ }^{4}$

Miles and Huberman, mengemukakan bahwa aktifitas dalam analisis data kualitatif dilakukan secara interaktif dan berlangsung secara terus menerus sampai tuntas. Aktifitas selama analisis data, yaitu data reduksi, display data, dan conclusion drawing atau verification. ${ }^{5}$

3Sanapiah Faesal, Dasar-dasardan Teknik Penelitian Keilmuan Sosial, Edisi Revisi, (Surabaya: Usaha Nasional, 2002), hlm. 42-43

4 S. Nasution, Metode Penelitian Naturalistik Kuantitatif, (Bandung: Tarsito, 2009), hlm. 127 hlm. 300

5Sugiyono, MetodologiPenelitianAdministrasi, (Bandung: CV Alfabeta, 2012), 


\section{Reduksi Data (Data Reduction)}

Kegiatan mereduksi data yaitu data mentah yang telah dikumpulkan dari hasil observasi, interview dan dokumentasi diklasifikasikan, kemudian diringkas agar mudah dipahami. Reduksi data ini merupakan suatu bentuk analisis yang bertujuan mempertajam, memilih, memfokuskan, menyusun data sedemikian rupa sehingga kesimpulan akhir dari penelitian dapat dibuat dan diverifikasi. ${ }^{6}$

\section{Display Data}

Display data (penyajian data) Miles and Huberman menyatakan yang paling sering digunakan untuk penyajian data dalam penelitian kualitatif adalah dengan teks yang bersifat naratif. ${ }^{7}$ Dengan sajian data tersebut membantu untuk memahami sesuatu yang sedang terjadi dan kemudian untuk membuat suatu analisis lebih lanjut berdasarkan pemahaman terhadap data yang disajikan tersebut. Oleh karena itu dengan permasalahan yang diteliti, data akan akan disajikan dalam bentuk tabel, matrik, grafik, dan bagan. Dengan penyajian seperti itu diharapkan informasi tertata dengan baik dan benar menjadi bentuk yang padat dan mudah dipahami untuk menarik sebuah kesimpulan.

\section{Conclusion Drawing/Verification}

Langkah ke tiga dalam analisis data kualitatif menurut Mile and Huberman adalah penarikan kesimpulan dan verifikasi. Kesimpulan awal yang dikemukakan masih bersifat sementara, dan akan berubah bila tidak ditemukan bukti- bukti yang kuat yang mendukung pada tahap pengumpulan data selanjutnya. Tetapi apabila kesimpulan yang dikemukakan pada tahap awal, dan di dukung oleh bukti-bukti yang valid dan konsisten saat peneliti kembali ke lapangan mengumpulkan data, maka kesimpulan yang dikemukakan merupakan kesimpulan yang kredibel. ${ }^{8}$

Menurut penulis, conclusion drawing/verification yaitu penyimpulan yang dimulai dari data-data yang telah disimpulkan, akan tetapi masih umum dan semu, kemudian apabila diteliti lebih lanjut akan semakin jelas karena data yang diperoleh semakin banyak dan mendukung.

6SubinoHadisubroto, Pokok-PokokPengumpulan data, Analisis Data, Penafsiran Data danRekomendasidalamPenelitianKualitatif, (Bandung: IKIP, 2009), hlm. 17

7Sugiyono, MetodePenelitianPendidikan, (Bandung: Alfabeta, 2010), hlm. 341

8Sugiyono, Op. Cit, hlm. 341 


\section{PEMBAHASAN}

\section{Sumber Daya Manusia UIN Raden Intan}

Sumber daya manusia UIN Raden Intan Lampung meliputi unsur tenaga dosen dan tenaga kependidikan. Jumlah sumber daya manusia yang dimiliki UIN Raden Intan saat ini yaitu: dosen tetap sejumlah 285 orang dan tenaga kependidikan sejumlah 177 orang.

\section{Dosen Tetap}

Dosen tetap UIN Raden Intan Lampung adalah tenaga pengajar dengan status pegawai negeri sipil (PNS) dan non PNS, yang bersangkutan di angkat untuk bertugas sesuai dengan keilmuan yang dimiliki. Keadaan dosen UIN Raden Intan Lampung dalam 5 tahun terakhir cenderung mengalami peningkatan. Faktor peningkatan tersebut terjadi karena semakin bertambahnya program studi baru di fakultas-fakultas yang berimplikasi akan adanya penambahan tenaga pengajar baru setiap tahun. Keadaan dosen tetap tahun 2012 sampai dengan tahun 2016 dapat dilihat pada tabel 4.1.

\section{Tabel 4.1. Keadaan Dosen Tetap dalam 5 Tahun Terakhir}

\begin{tabular}{|c|c|c|c|c|c|c|}
\hline \multirow[t]{2}{*}{ No } & \multirow[t]{2}{*}{ Fakultas } & \multicolumn{5}{|c|}{ Tahun } \\
\hline & & 2012 & 2013 & 2014 & 2015 & 2016 \\
\hline 1 & Tarbiyah dan Keguruan & 108 & 109 & 112 & 131 & 131 \\
\hline 2 & Syari'ah & 71 & 71 & 67 & 48 & 48 \\
\hline 3 & Ushuluddin & 50 & 48 & 46 & 45 & 45 \\
\hline 4 & Dakwah dan Ilmu Komunikasi & 37 & 37 & 37 & 34 & 34 \\
\hline 5 & Ekonomi dan Bisnis Islam & - & - & - & 27 & 27 \\
\hline & Jumlah & 266 & 265 & 262 & 285 & 285 \\
\hline
\end{tabular}

Sumber: Data Kepegawaian UIN Raden Intan 2017

Jumlah dosen tetap dari tahun 2012 sampai 2016 untuk fakultas Syariah, Ushuludin, dan dakwah mengalami penurunan, kecuali fakultas Tarbiyah dan Keguruan dan FEBI. Kemudian jika dibandingkan antara tahun 2012 dengan 2016 dari segi jumlah memperlihatkan peningkatan yaitu $0,067 \%$.

Pada tabel di atas jumlah dosen PPs memang tidak ditampilkan karena dosen yang mengajar yang di PPs termasuk dalam dosen yang mengajar di fakultas yang ada di lingkungan UIN Raden Intan Lampung . 
Tabel 4.2 Dosen Tetap Berdasarkan Jenjang Pendidikan Dalam 5 Tahun Terakhir

\begin{tabular}{|l|l|l|l|l|l|l|}
\hline \multirow{2}{*}{ No } & Jenjang & \multicolumn{5}{c|}{ Pendidikan } \\
\cline { 3 - 7 } & & 2012 & 2013 & 2014 & 2015 & 2016 \\
\hline 1 & Doktor (S.3) & 55 & 63 & 67 & 74 & 78 \\
\hline 2 & Magister (S.2) & 203 & 195 & 188 & 204 & 207 \\
\hline 3 & Sarjana (S.1) & 8 & 7 & 7 & 7 & 0 \\
\hline \multicolumn{2}{|c|}{ Jumlah } & 266 & 265 & 262 & 285 & 285 \\
\hline
\end{tabular}

Sumber: Data Kepegawaian IAIN Raden Intan 2016

Dosen yang berpendidikan S3 memang mengalami peningkatan setiap tahun. Hal ini telah menjadi dorongan di kalangan dosen karena menjadi persyaratan untuk mendapatkan jenjang kenaikan pangkat menjadi Guru Besar.

\section{Dosen Tidak Tetap}

Dosen tidak tetap disebut juga dosen luar biasa merupakan dosen dari luar UIN Raden Intan Lampung yang diminta oleh fakultas untuk mengampu mata kuliah keahlian tertentu karena dalam fakultas tersebut tidak/belum memiliki dosen yang ahli sesuai yang dibutuhkan. Secara umum jumlah dosen luar biasa mengalami kenaikan seiring dengan peningkatan jumlah mahasiswa yang berimplikasi terhadap bertambahnya jumlah lokal di fakultas setiap tahunnya. Namun berdasarkan kebijakan Rektor UIN Raden Intan mengenai status dosen luar biasa hanya akan diberikan dosen yang berasal luar UIN Raden Intan Lampung, sehingga dosen tetap pada fakultas yang mengajar pada fakultas lain dalam lengkungan UIN tidak lagi diakui sebagai dosen luar biasa melainkan pengampuan mata kuliah wajib yang dihitung kelebihan mengajar.

Keadaan dosen luar biasa (DLB) termasuk kategori dosen tidak tetap. Dalam 5 tahun terakhir kondisi DLB sebagaimana tertera dalam tabel berikut ini, yang masing masing fakultas tidak sama jumlahnya. Disini tampak jumlah DLB pada tahun 2016 yang paling banyak adalah fakultas Tarbiyah dan Keguruan (253 orang), sedangkan jumlah yang paling sedikait adalah fakultas Syari'ah (33) orang, jumlah DLB terbnyak kedua adalah FEBI (57 orang), ketiga Dakwah dan ilmu Komunikasi ( 55 orang), Ushuluddin (52 orang)

Tabel 4.3. Keadaan Dosen Luar Biasa 5 Tahun Terakhir

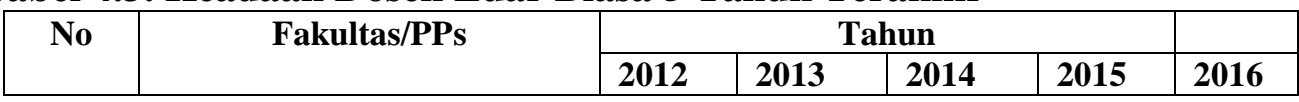




\begin{tabular}{|l|l|l|l|l|l|l|}
\hline 1 & Tarbiyah dan Keguruan & 141 & 159 & 165 & 253 & 253 \\
\hline 2 & Syari'ah & 31 & 23 & 25 & 33 & 33 \\
\hline 3 & Ushuluddin & 8 & 6 & 10 & 52 & 52 \\
\hline 4 & $\begin{array}{l}\text { Dakwah dan Ilmu } \\
\text { Komunikasi }\end{array}$ & 12 & 13 & 15 & 55 & 55 \\
\hline 5 & Ekonomi dan Bisnis Islam & 0 & 0 & 0 & 57 & 57 \\
\hline 6 & Program Pascasarjana & 34 & 16 & 18 & 77 & 77 \\
\hline \multicolumn{2}{|}{ Jumlah } & $\mathbf{2 2 6}$ & $\mathbf{2 1 7}$ & $\mathbf{2 3 3}$ & $\mathbf{5 2 7}$ & $\mathbf{5 2 7}$ \\
\hline
\end{tabular}

Sumber: Data Kepegawaian IAIN Raden Intan 2017

Saat ini, keberadaan dosen luar biasa pada masing-masing fakultas masih diperlukan. Hal ini disebabkan masih terbatasnya jumlah dosen tetap dibandingkan dengan jumlah program studi dan jumlah mahasiswa yang terus bertambah.

\section{Tenaga Kependidikan Tetap (PNS)}

Tenaga administrasi UIN Raden Intan Lampung sebagian besar bersatus Pegawai Negeri Sipil (PNS). Penempatan dan kenaikan pangkat tenaga administrasi didasarkan pada Undang-Undang Kepegawaian. Pengangkatan pegawai administrasi dalam suatu jabatan struktural diperlukan pertimbangan yang dilakukan oleh badan pertimbangan jabatan dan kepangkatan sesuai job atau jabatan yang tersedia dalam stuktur yang telah dibentuk sebelumnya. Tenaga administrasi tersebut di UIN Raden Intan Lampung sangat besar peranannya dalam memberikan pelayanan dibidang administrasi, baik pelayanan pada mahasiswa tenaga administrasi PNS UIN Raden Intan Lampung dapat dilihat pada tabel di bawah ini:

\section{Tabel 4.4 Keadaan Tenaga Kependidikan PNS 5 Tahun Terakhir}

\begin{tabular}{|c|c|c|c|c|c|c|}
\hline \multirow[t]{2}{*}{ No } & \multirow[t]{2}{*}{ Unit Kerja } & \multicolumn{4}{|c|}{ Tahun } & \multirow[b]{2}{*}{2016} \\
\hline & & 2012 & 2013 & 2014 & 2015 & \\
\hline 1 & Rektorat & 118 & 110 & 109 & 105 & 105 \\
\hline 2 & Tarbiyah \& Keg. & 20 & 22 & 20 & 20 & 20 \\
\hline 3 & Syari'ah & 19 & 20 & 19 & 18 & 18 \\
\hline 4 & Ushuluddin & 13 & 12 & 11 & 11 & 11 \\
\hline 5 & Dakwah \& IK & 14 & 14 & 14 & 14 & 14 \\
\hline 6 & FEBI & - & - & - & 1 & 1 \\
\hline 7 & Pasca Sarjana & 9 & 9 & 9 & 8 & 8 \\
\hline & Jumlah & 193 & 187 & 182 & 177 & 177 \\
\hline
\end{tabular}

Sumber: Data Kepegawaian UIN Raden Intan 2017

Selanjutnya jumlah Pegawai atau tenaga Kependidikan di UIN Raden Intan Lampung sejak empat tahun terakhir dapat dilihat dalam tabel tersebut menyajikan bahwa jumlah pegawai yang berstatus PNS dalam kurun waktu 5 tahun terakhir secara keseluruhan mengalami penurunan. Hanya Fakultas Dakwah yang jumlahnya tetap. Sedangkan Tenaga kependidikan 
berdasarkan klasifikasi jabatan fungsional Umum dan Jabatan Khusus, Sebagai berikut:

Tabel 4.5 Tenaga Administrasi Fungsional Khusus PNS 5 Tahun Terakhir

\begin{tabular}{|l|l|l|l|l|l|l|l|l|l|}
\hline \multirow{2}{*}{ No } & \multirow{2}{*}{ Jabatan } & $\mathbf{2 0 1 3}$ & \multicolumn{2}{l|}{$\mathbf{2 0 1 4}$} & \multicolumn{2}{l|}{$\mathbf{2 0 1 5}$} & \multicolumn{2}{l|}{$\mathbf{2 0 1 6}$} \\
\cline { 2 - 11 } & & Lk & Pr & Lk & Pr & Lk & Pr & Lk & Pr \\
\hline 1 & Tenaga administrasi & 99 & 69 & 99 & 65 & 101 & 60 & 103 & 59 \\
\hline 2 & Pustakawan & 1 & 4 & 1 & 3 & 1 & 4 & 1 & 4 \\
\hline 3 & Arsiparis & 3 & 0 & 3 & 0 & 3 & 0 & 3 & 0 \\
\hline 4 & Analisis kepegawaian & 3 & 0 & 3 & 0 & 3 & 0 & 2 & 0 \\
\hline 5 & Pranata komputer & 3 & 0 & 1 & 0 & 3 & 0 & 3 & 0 \\
\hline 6 & Pranata humas & 1 & 0 & 1 & 0 & 1 & 0 & 1 & 0 \\
\hline 7 & Statitisi & 1 & 1 & 1 & 1 & 1 & 1 & 1 & 0 \\
\hline 8 & Tenaga lainnya (satpam) & 2 & 0 & 2 & 0 & 2 & 0 & 0 & 0 \\
\hline & Jumlah & 113 & 74 & 113 & 69 & 115 & 65 & 115 & 63 \\
\hline Jumlah Total & $\mathbf{1 8 7}$ & $\mathbf{1 8 2}$ & $\mathbf{1 8 0}$ & $\mathbf{1 7 7}$ & \\
\hline
\end{tabular}

Sumber: Data Kepegawaian UIN Raden Intan 2017

\section{Tenaga Kependidikan Honorer}

Tenaga administrasi UIN Raden Intan selain berstatus PNS juga terdapat tenaga administrasi "kontrak" dan honorer. Keberadaan mereka di UIN Raden Intan sangat penting perannya dalam rangka peningkatan pelayanan yang diberikan terhadap dosen dan masyarakat umum lainnya. Jumlah administrasi yang berstatus honor seperti tabel dibawah ini:

Tabel 4.7 Tenaga Administrasi Honorer dalam 5 Tahun Terakhir

\begin{tabular}{|l|l|l|l|l|l|l|}
\hline \multirow{2}{*}{ No } & \multirow{2}{*}{ UNIT KERJA } & \multicolumn{5}{c|}{ TAHUN } \\
\cline { 3 - 8 } & & $\mathbf{2 0 1 2}$ & $\mathbf{2 0 1 3}$ & $\mathbf{2 0 1 4}$ & $\mathbf{2 0 1 5}$ & $\mathbf{2 0 1 6}$ \\
\hline 1 & Rektorat & 14 & 14 & 10 & 13 & 13 \\
\hline 2 & Tarbiyah dan Keguruan & 4 & 4 & 3 & 3 & 3 \\
\hline 3 & Syari'ah & 2 & 2 & 2 & 2 & 2 \\
\hline 4 & Ushuluddin & 1 & 1 & - & - & - \\
\hline 5 & Dakwah dan Ilmu Komunikasi & - & - & - & - & - \\
\hline 6 & Ekonomi dan Bisnis Islam & - & - & - & - & - \\
\hline \multicolumn{2}{|c|}{ Jumlah } & $\mathbf{2 1}$ & $\mathbf{2 1}$ & $\mathbf{1 5}$ & $\mathbf{1 8}$ & $\mathbf{1 8}$ \\
\hline
\end{tabular}

Sumber: Data Kepegawaian UIN Raden Intan 2017

\section{Rasio Dosen Tetap dengan Tenaga Kependidikan Tetap}


Rasio perbandingan dosen dengan administrasi UIN Raden Intan dapat dilihat pada tabel di bawah ini:

Tabel 4.9 Rasio Dosen dengan TenagaAdministrasi 5 Tahun Terakhir

\begin{tabular}{|c|c|c|c|c|}
\hline No & Tahun & $\begin{array}{l}\text { Jumlah Tenaga } \\
\text { Administrasi PNS }\end{array}$ & $\begin{array}{l}\text { Jumlah Dosen } \\
\text { Tetap }\end{array}$ & Ratio \\
\hline 1 & 2012 & 193 & 266 & $1: 3$ \\
\hline 2 & 2013 & 187 & 265 & $1: 4$ \\
\hline 3 & 2014 & 182 & 262 & $1: 4$ \\
\hline 4 & 2015 & 177 & 285 & $1: 6$ \\
\hline 5 & 2016 & 177 & 285 & $1: 6$ \\
\hline
\end{tabular}

Sumber: Data Kepegawaian UIN Raden Intan 2017

\section{Pengembangan SDM UIN Raden Intan}

Dalam rangka peningkatan produktivitas kinerja pegawai, banyak hal telah dilakukan UIN Raden Intan . Peningkatan kualitas SDM menjadi suatu keharusan karena menjadi faktor pendukung utama tercapainya VisiMisi yang telah dibangun. Sebagaimana yang telah dikemukakan pada kajian teori, banyak sekali teknik atau metode pengembangan SDM yang bisa digunakan dan semuanya memiliki keunggulan masing-masing.

Peneliti dalam konteks ini mencoba menganalisis apa yang telah di lakukan oleh UIN Raden Intan sejak beberapa tahun terakhir terkait pengembangan SDM dan mengkorelasikannya dengan teknik-teknik yang ada. Berikut ini dipaparkan data kegiatan pengembangan SDM di lingkungan UIN Raden Intan yang telah dilaksanakan:

\section{Metode praktis (On the Job Training)}

$\mathrm{On}$ the Job Training (OJT) merupakan metode latihan pengembangan SDM di UIN Raden Intan Lampung yang paling banyak digunakan. Selanjutnya berbagai ragam teknik yang digunakan dalam praktek OJT antara lain :
a. Rotasi jabatan;
b. Latihan instruksi pekerjaan; .
c. Magang (apprenticeships);
d. Coaching/pendampingan;
e. Penugasan sementara;
f. On the job training
On the job training 


\section{Job Instruction Training}

3. Belajar Secara Informal

Belajar secara informal dilakukan dengan tidak formal terkait dengan regulasi administrasi terbaru maupun teknik aplikasi IT terkini sesuai dengan kebutuhan dan penguatan Sistem Informasi dan Teknologi pada UIN Raden Intan

Media pembelajaran berupa buku teks, hand out, komputer dan internet, pelajaran yang terprogram (atau instruksi terprogram) adalah metode belajar-sendiri-langkah-demi-langkah yang terdiri dari tiga bagian, yaitu:

a. Menyajikan pertanyaan, fakta atau permasalahan kepada orang yang belajar

b. Mengijinkan orang itu untuk memberikan respon

c. Memberikan timbal-balik untuk mendapatkan jawaban yang akurat

\section{Pelatihan dengan Peralatan Audiovisual}

Teknik pelatihan dengan menggunakan audiovisual seperti film, powerpoint, video konperensi, kaset audio, dan kaset video bisa sangat efektif dan telah banyak digunakan. Audiovisual biayanya lebih mahal daripada pengajaran konvensional tetapi memiliki beberapa keuntungan. Tentu saja, audiovisual cenderung menjadi lebih menarik. Sebagai tambahan, pertimbangkan penggunaan audiovisual dalam situasi berikut:

a. Ketika dibutuhkan ilustrasi mengenai rangkaian tertentu selama beberapa waktu, seperti mengajari perbaikan mesin fax. Kemampuan audiovisual untuk dihentikan, diulang, dan dipercepat atau diperlambat bisa sangat berguna.

b. Ketika dibutuhkan bentuk latihan dengan kejadian yang tidak mudah didemonstrasikan dengan pengajaran langsung, seperti tur visual pada pabrik atau oprasi jantung.

c. Ketika dibutuhkan pelatihan untuk seluruh organisasi dan terlalu mahal untuk memindahkan para pelatih dari tempat yang satu ke tempat lainnya.

\section{Pelatihan Dengan Simulasi}

Pelatihan simulasi (terkadang disebut pelatihan di ruang depan) adalah sebuah metode dimana orang-orang yang dilatih belajar dengan peralatan yang sebenarnya atau dengan simulasi yang akan digunakan dalam pekerjaan, tetapi sebenarnya mereka dilatih di luar pekerjaan. Hal ini diperlukan karena terlalu mahal atau terlalu berbahaya melatih karyawan pada pekerjaan. Misalnya, menempatkan para pekerja baru pada link-perakitan bisa memperlambat produksi, dan untuk pelatihan yang menyangkut keamanan seperti pelatihan untuk pilot, pelatihan tersimulasi mungkin menjadi satusatunya alternatif paling praktis.

\section{Pelatihan Elektronik}

Peralatan komputer yang berbasis-Internet telah membuat revolusi dalam proses pelatihan. Metode khusus merupakan pelatihan berbasiskomputer, sistem elektronik pendukung prestasi dan portal belajar. 


\section{Pelatihan Berbasis-Komputer}

8. Elektronic Performance Support System/ Bantuan pekerjaan Elektronik

9. Pelatihan Jarak Jauh Berbasis-Internet

Perusahaan saat ini menggunakan beragam metode belajar jarak jauh untuk pelatihan. Metode belajar jarak jauh diantaranya adalah kursus korespondensi tertulis tradisional, teletraining, video konperensi, dan pelatihan berbasis Internet.

10. Teletraining

Dengan teletraining, seorang pelatih di pusat mengajar kelompokkelompok karyawan di lokasi yang jauh melalui sambungan televisi.

11. Pelatihan Melalui Internet.

Dalam rangka peningkatan SDM UIN Raden Intan kemempuan IT pun ditingkatkan melalui pelatihan internet dan/atau intranet.

12. Portal Belajar

Dalam hal PEnguatan Karakter pegawai, dilakukan pelatihan sebagai berikut;

\section{Spiritual Motivation Training}

Pelatian ini dilaksanakan pada tahun 2012 dan diikuti peserta sekitar 115 orang yang merupakan perwakilan dari Rektorat, Dekan dan prodi (jurusan) di seluruh civitas akedmika IAIN Raden Intan . Pelatihan ini sendiri dimaksudkan untuk membangkitkan ethos kerja dan mengokohkan komitmen para pejabat di lingkungan IAIN Raden Intan ..

2. Kegiatan Outbond Pengembangan Karakter

3. Ice Breaking, Low Element (Flying Carpet; Water Transfer; Flying Ball; Spider Puzzle) b.Racing Game (Kapal Perang; Jump; Scorpion Race; How Long You Can Go; Spirit of Fire; 4. In house training (Fundamental Communication Team, Spirit in Action Team

4. Spiritual Motivasion Question (SMQ)

\section{PENUTUP}

Berdasarkan uraian di atas Mengapa Sumber Daya Manusia di UIN Raden Intan perlu dikembangkan ? Hal ini karena untuk meningkatkan kompetensi dan profesionalisme pegawai menghadapi volume pekerjaan yang semakin besar dan membutuhkan keterampilan dan ketelitian berbasis IT, sehingga pekerjaan dapat diselesaikan dengan efektif dan efisien

Adapun Karakteristik Metode-Metode Pengembangan Sumber Daya Manusia yang telah dilakukan di UIN Raden Intan Bandarlamung dapat dikategorikan menjadi Pengembangan SDM berbasis kognitif, afektif dan psikomotorik. Pengembangan berbasis kognitif berupa pelatihan informal terkait pengembangan wawasan ruang lingkup pekerjaan, serta tugas dan tanggung jawab pekerjaan. Pengembangan berbasis Afektif dilakukan dengan pelatihan berbasis karakter yaitu melalui pelatian kepemimpinan dan 
penguatan afeksi berupa out bond dan pembinaan mental spiritual. Selanjutnya pengembangan SDM berbasis Psikomotorik mengacu pada keterampilan fisik atau skills, hal ini dilakukan dengan pelatihan pegawai berbasis ICT, hal ini sebagai bentuk penguatan di bidang informasi, telekomunikasi dan komputerisasi sebagai alat transformasi akademik, administrasi dan birokrasi.

Selanjutnya terkait dengan bagaimana Langkah-Langkah Metode Pengembangan Sumber Daya Manusia, hal ini dilakukan dengan cara On the Job Training, in service training, out bond, workshop berbasis IT, Rotasi jabatan, Latihan instruksi pekerjaan, Magang (apprenticeships), Coaching/pendampingan, Penugasan sementara, Spiritual Motivation Training, dan Spiritual Motivation Question.

Adapun Implikasi Pengembangan Sumber Daya Manusia bagi pegawai UIN Raden intan dapat dilihat bahwa secara kognitif, pegawai UIN Raden Intan Lampung mengalami peningkatan wawasan keilmuan, wawasan kerja dan wawasan berfikir terkait dengan bidang kerjanya, tantangan kerja dan peluang kerja yang dihadapinya pada sekarang dan yang akan datang.

Padat tataran afektif, pegawai UIN Raden Intan Lampung memiliki kesadaran diri untuk terus "Update" terhadap perkembangan dan kemajuan ICT sehingga dirinya bisa terus beradaptasi dan mengimbangi derasnya arus perubahan informasi dan transformasi berbasis teknologi dan komputerisasi. Mereka juga ada rasa tanggung jawab kerja sesuai dengan bidang kerjanya. Dan pada aspek psikomotorik penguasaan dan keterampilan di bidang teknologi dan komputerisasi semakin kuat, hal ini tampak dari keterampilan pegawai mejalankan aplikasi administrasi perkantoran dan keuangan pada masing-masing bidang, serta bidang akademik dengan jaringan "online".

\section{DAFTAR PUSTAKA}

Abdurrahman Fathoni, Metodologi Penelitian dan Teknik Penyusunan

Skripsi, Jakarta: Rineka Cita, 2011

Asrori Imam, Aneka Permainan (Penyegar Pembelajaran Bahasa Arab),

Surabaya : Hilal Pustaka, 2009.

Djam'an Santori Dan Aan Komariah, Metode Penelitian Kualitatif,

Bandung : CV, Alfabet, 2010

Gulo, Metodologi Penelitian, (Jakarta: PT. Grasindo, Cet. 1, 2002

Hasibuan Malayu, Manajemen Sumber Daya Manusia, Cet. III, CV. Jakarta,

CV. Haji Mas Agung, 1996 
Husaini Usman, Manajemen, Jakarta : Bumi Aksara, 2009

Jawahir Tanthowi, Unsur-Unsur Manajemen Menurut Ajaran Al-Qur'an, Jakarta : Pustaka Al-Huda, 1983

M. Kadarisman, Manajemen Pengembangan Sumber Daya Manusia, Jakarta,

Raja Grafindo Persada, 2012

Manullang, M., 2006, Manajemen Personalia, Jakarta, Gajahmada Press,

Moleong, Metode Penelitian Kualitatif, Bandung : Rosdakarya, 2001

Muhammad Farouk \& Djaali, Metodologi Penelitian Sosial, Jakarta: Restu Agung, 2003

Nana Sudjana, Penelitian dan Penilaian Pendidikan, Bandung: Sinar Baru, 2009

Richhard, H, Hastrop, Managing Education For Result, 1975

S. Nasution, Metode Penelitian Naturalistik Kuantitatif, Bandung: Tarsito, 2009

, Metode Research, Jakarta : PT Bumi Aksara, 2008

Sanapiah Faesal, Dasar-dasar dan Teknik Penelitian Keilmuan Sosial, Edisi

Revisi, Surabaya: Usaha Nasional, 2002

Saydam, Gouzali, Manajemen Sumber Daya Manusia Human Resources

Management : Suatu Pendekatan Mikro (Dalam Tanya Jawab),

Jakarta, Penerbit Djamabatan, Cet. II, 2000

Singarimbun Masri dan Effendi Sorfan, Metode Penelitian Survey, Jakarta:

LP3ES, 2011

Subino Hadisubroto, Pokok-Pokok Pengumpulan data, Analisis Data,

Penafsiran Data dan Rekomendasi dalam Penelitian Kualitatif,

Bandung: IKIP, 2009

Sudarwan Denim, Visi Baru Manajemen Sekolah, Jakarta:PT Bumi Aksara, 2006

Sugiyono, Metode Penelitian Pendidikan, Bandung: Alfabeta, 2010 , Metodologi Penelitian Administrasi, Bandung: CV Alfabeta, 2012

Sutrisno Hadi, Metodologi Reserch, Yogyakarta: Andi Ofset, Edisi Revisi, 2002 